\title{
Effectiveness of two-sided UV-C treatments in inhibiting natural microflora and extending the shelf-life of minimally processed 'Red Oak Leaf' lettuce
}

\author{
Ana Allende ${ }^{\mathrm{a}}$, James L. McEvoy ${ }^{\mathrm{b}, *}$, Yaguang Luo ${ }^{\mathrm{b}}$, Francisco Artes ${ }^{\mathrm{c}}$, Chien Y. Wang ${ }^{\mathrm{b}}$ \\ ${ }^{a}$ Department of Food Science and Technology, CEBAS-CSIC, P.O. Box 4195, 30080 Murcia, Spain \\ ${ }^{\mathrm{b}}$ Produce Quality and Safety Laboratory, Plant Science Institute, Henry A. Wallace Agricultural Research Center, \\ USDA-ARS, Bldg. 002, BARC-West, Beltsville, MD 20705, USA \\ ${ }^{\mathrm{c}}$ Postharvest and Refrigeration Group, Department of Food Engineering, Technical University of Cartagena, \\ Paseo Alfonso XIII, 48. 30023 Cartagena, Spain
}

Received 15 December 2004; received in revised form 26 April 2005; accepted 26 April 2005

Available online 28 July 2005

\begin{abstract}
The use of UV-C radiation treatments to inhibit the microbial growth and extend the shelf-life of minimally processed 'Red Oak Leaf' lettuce was investigated. Initially, UV-C resistance of 20 bacterial strains from different genera often associated with fresh produce (Enterobacter, Erwinia, Escherichia, Leuconostoc, Pantoea, Pseudomonas, Rahnela, Salmonella, Serratia and Yersinia) were tested in vitro. Most of the bacterial strains were inhibited with the minimum dose $\left(30 \mathrm{~J} \mathrm{~m}^{-2}\right)$. Erwinia carotovora, Leuconostoc carnosum, Salmonella typhimurium, and Yersinia aldovae were the most resistant strains requiring a UV-C dose of $85 \mathrm{~J}^{-2}$ to completely inhibit growth. An in vivo study consisted of treating minimally processed 'Red Oak Leaf' lettuce (Lactuca sativa) with UV-C at three radiation doses $\left(1.18,2.37\right.$ and $\left.7.11 \mathrm{~kJ} \mathrm{~m}^{-2}\right)$ on each side of the leaves and storing the product under passive MAP conditions at $5{ }^{\circ} \mathrm{C}$ for up to 10 days. The gas composition inside packages varied significantly among the treatments, with $\mathrm{CO}_{2}$ concentrations positively and $\mathrm{O}_{2}$ concentrations negatively correlating with the radiation dose. All the radiation doses were effective in reducing the natural microflora of the product, although the highest doses showed the greatest microbial inhibitions. Taking into account the microbial limit set by Spanish legislation [Boletín Oficial del Estado (BOE), 2001. Normas de higiene para la elaboración, distribución y comercio de comidas preparadas, Madrid, Spain, Real Decreto 3484/2000, pp. 1435-1441], all UV-C treatments extended the shelf-life of the product. However, the $7.11 \mathrm{~kJ} \mathrm{~m}^{-2}$ dose induced tissue softening and browning after 7 days of storage at $5{ }^{\circ} \mathrm{C}$. Therefore, the use of two sided UV-C radiation, at the proper dose, is effective in reducing the natural microflora and extending the shelf-life of minimally processed 'Red Oak Leaf' lettuce.
\end{abstract}

(C) 2005 Elsevier Ltd. All rights reserved.

Keywords: Ultraviolet light (254 nm); Fresh-cut; Microbial growth; Sensory quality; Gas composition

\section{Introduction}

The increased demand of fresh minimally processed vegetables has led to an increase in the quantity and variety of produce available to the consumer in the markets (Francis et al., 1999). Since the last decade,

\footnotetext{
*Corresponding author. Tel.: + 13015046983 ; fax: + 13015045107 .

E-mail address: mcevoyj@ba.ars.usda.gov (J.L. McEvoy).
}

lettuce and chicory salads, cabbage and other analogous vegetables are still the most consumed fresh processed vegetables (Nguyen-the and Carlin, 1994). One of the most demanded types of lettuce to be incorporated in mixed salads is 'Red Oak Leaf' lettuce (Lactuca sativa var. crispa). This is a leaf lettuce, which is distinguished from other varieties in that it does not have a 'head' and produces an abundance of dark green and red oak shaped leaves. This lettuce is crisp and has a good flavor with a sweet aftertaste, but is more perishable than head 
lettuces. The limited shelf-life of fresh processed leafy lettuces is one of the greatest problems faced by commercial marketers (Soliva-Fortuny and MartínBelloso, 2003) mainly due to the natural variability in the material. Worldwide, all fresh-cut products are by necessity handled in modified atmosphere packaging (MAP) to achieve the necessary post-harvest lifespan (Brecht et al., 2003). However, it is very difficult to identify an optimal storage atmosphere with the current techniques and methodologies (Saltveit, 2003). Thus, efforts are made to optimize processing to reduce losses from microbial spoilage as well as the design of moderate but workable alternative preservation treatments.

A good procedure to reduce the microbial risk involved with the consumption of fresh fruits and vegetables includes the reduction or elimination of external contamination by using surface decontamination techniques (Yaun et al., 2004). A superficial postharvest treatment that can be an adjunct to refrigeration for preserving fruit and vegetables is the use of nonionizing, germicidal, artificial ultraviolet (UV-C) radiation (Maharaj et al., 1999). This treatment brings some benefits to the fresh cut industry as its use is approved by the code of Food and Drug Administration (FDA) in the USA (Rhim et al., 1999) on food products to control surface micro-organisms, does not leave a residue, and does not require extensive safety equipment (Yousef and Marth, 1988; Wong et al., 1998; Yaun et al., 2004). Several in vitro studies have demonstrated the efficiency of UV-C radiation on microbial inhibition (Gardner and Shama, 2000). Abshire and Dunton (1981), exposed several micro-organisms to UV-C treatments and demonstrated that low UV intensity penetrated sufficiently through polyethylene bottles of saline suspensions to obtain a total kill of $10^{6}$ or $10^{7}$ cells per $\mathrm{ml}$ in very short periods of time. They also found that some strains (Pseudomonas aeruginosa) were more sensitive than others (Micrococcus radiodurans and Candida albicans). Consistent with this, Sumner et al. (1995) found that UV-C was effective in destroying Salmonella typhimurium on agar plates and Yaun et al. (2004) observed that five Salmonella and Escherichia coli O157:H7 strains inoculated in lettuce showed similar logarithmic reductions when treated with the same doses of UV-C radiation. Additionally, many researchers showed that UV-C radiation was effective in inhibiting growth of different micro-organisms commonly present in food products (Abshire and Dunton, 1981; Bintsis et al., 2000; El-Ghaouth and Wilson, 1995; Sommer et al., 1996, 2000) and some of them demonstrated the efficacy of UV-C radiation for reducing microbial growth in fruit and vegetables (Marquenie et al., 2003; Stevens et al., 1998; Vicente et al., 2005). Of special interest is the development of an UV-C apparatus, which delivered low-dose UV-C light to the surface of fruit on a processing line (Wilson et al., 1997).
However, only a few studies have focused on UV-C radiation of minimally processed fruit and vegetables (Allende and Artes, 2003a, b; Erkan et al., 2001) and all of them radiated the product only on one side of the tissue. The overall objective of this study was to determine the efficiency of three UV-C radiation doses on the in vitro growth of different vegetable-associated micro-organisms and the microbial reduction of the resident microflora of fresh processed 'Red Oak Leaf' lettuce when applied to both sides of the tissue.

\section{Materials and methods}

\subsection{In vitro study}

The potential antimicrobial effect of UV-C radiation to reduce or inhibit the growth of different bacterial strains of the natural microflora of minimally processed vegetables was evaluated. Stock cultures of Enterobacter cloacae, Enterobacter asburiae, Erwinia carotovora ECC71, E. coli $\mathrm{RecA}^{-} \mathrm{HB} 101$ and $\mathrm{RecA}^{+} \mathrm{MC} 4100$, Escherichia vulneus, Escherichia hermannii, Leuconostoc carnosum, Pantoea agglomerans, Pseudomonas fluorescens Biotype G and A, Pseudomonas corrugata, Pseudomonas putida C552, Pseudomonas tolasii, Rahnela aquatilis, Salmonella typhimurium, Serratia ficaria, Serratia plymuthica, Serratia liquefaciens, and Yersinia aldovae were provided by the Produce Quality and Safety Laboratory (Culture Collection, PQSL, Plant Science Institute, USDA, Beltsville, Maryland, USA) as samples stored at $-80{ }^{\circ} \mathrm{C}$ in equal volumes of glycerol $(50 \%$ in distilled water) and nutrient broth $(50 \%)$. All the strains were isolated, biochemically characterized and identified with a Biolog MicroLog System, Release 4.01B (Biolog, Inc., Hayward, California, USA) (Bhagwat, unpublished data). Working cultures were subcultured twice on nutrient agar (Difco Lab, Sparks, Maryland, USA) for $24 \mathrm{~h}$ at 30 or $37^{\circ} \mathrm{C}$ for enteric micro-organisms. Nutrient agar was chosen as the cultivation medium because of its non-selective value. The second subculture was diluted to approximately $1 \times 10^{8}$ cells ml ${ }^{-1}$ in nutrient broth and a loop full was streaked across a nutrient agar plate. After inoculation, plates were subjected to five UV-C radiation treatments $\left(30,55,85,115\right.$ and $\left.140 \mathrm{~J} \mathrm{~m}^{-2}\right)$ by using a UVP lamp (Model UVLMS-38: 3UV EL Series UVLamp, 8W, LW/MR/SW, Upland, California, USA) equipped with a filter (98-0016-02, Upland, California, USA) to have only one wavelength at $254 \mathrm{~nm}$ with an intensity of $300 \mu \mathrm{W} \mathrm{cm} \mathrm{cm}^{-2}$ at a distance of $18 \mathrm{~cm}$. The intensity of the UV-C lamp was determined with a Blak-Ray J-225 photometer. Radiation and subsequent incubation of the plates were performed in the dark to minimize bacterial photoreactivation (Schoenen and Kolch, 1992). Plates were incubated for $24 \mathrm{~h}$ and the treatment 


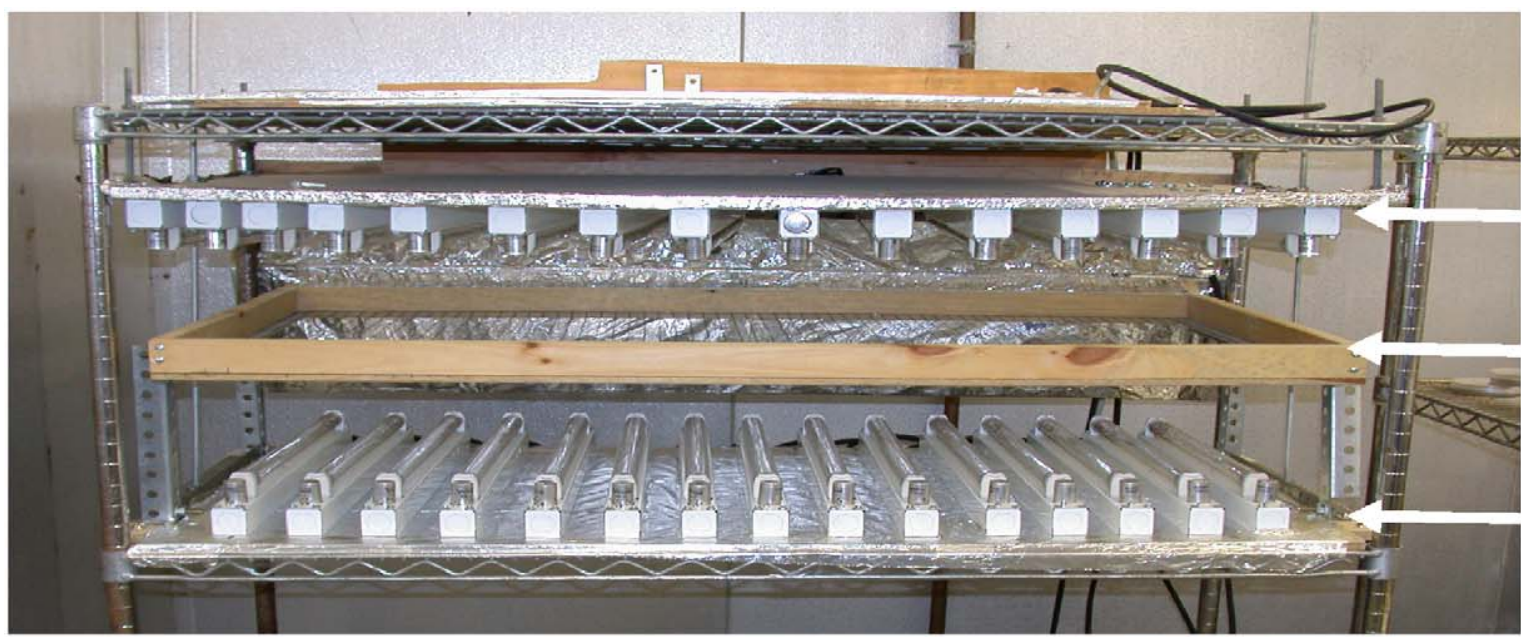

Upper Lights

Produce 'Tray

Fig. 1. UV-C radiation device. The arrows indicate the upper and lower groups of UV-C lights and the produce tray consisting of a polystyrene net and wooden frame.

efficiency was evaluated by examining bacterial growth on the agar plates.

\section{2. 'Red Oak Leaf' lettuce}

\subsubsection{Minimally processing of lettuce}

'Red Oak Leaf' lettuce was cultivated in Mexico and obtained from a local wholesale market in Jessup (Maryland, USA) on the day of their arrival and transported to the fresh-cut Produce Quality and Safety Laboratory ( $30 \mathrm{~min}$ ) under refrigeration conditions. The lettuce was immediately processed in a fresh-cut preparation room at $10{ }^{\circ} \mathrm{C}$ upon arrival. Outer leaves and kernels were removed and lettuce leaves were then cut into approximately $4 \times 4 \mathrm{~cm}^{2}$ with a sharp stainless steel knife. Cut lettuce was washed in chlorinated water $(150 \mathrm{ppm})$ and tap water rinsed at $10^{\circ} \mathrm{C}$. The excess water was removed by centrifugation in a salad spinner (OXO Good Grips, Elmira, New York, USA) for $30 \mathrm{~s}$. Finally, the product was placed in polystyrene plastic trays of approximately $50 \times 100 \times 50 \mathrm{~cm}^{3}$ (PCA Co, Wheeling, Illinois, USA) and stored at $10{ }^{\circ} \mathrm{C}$ for no longer than an hour to avoid any detrimental effect on the organoleptical quality of the product before the UV-C treatment was applied.

\subsection{2. $U V$-C radiation treatments and packaging}

The UV-C radiation device consisted of two banks of 15 stainless-steel reflectors with unfiltered germicidal emitting lamps (FG15T8-15 W T8 120 V germicidal lamp GRM-0152, Atlanta Light Bulbs Inc., Tucker, Georgia, USA) located $15 \mathrm{~cm}$ above and below the radiation vessel (Fig. 1). The UV-C intensities of the emitting lamps were determined by using a Blak-Ray J-225 photometer (Ultra-Violet Products, Inc., San Gabriel, California, USA). Although a small amount of infrared radiation was also emitted, $98.7 \%$ of the total emitted light was in the UV-C (220-290 nm, with peak radiation at approximately $254 \mathrm{~nm}$ ) region. The UV-C lamps, reflectors, and treatment area were enclosed in a wooden box covered with aluminum foil and supported by a metal framework to provide protection for the operators. The different UV-C radiation doses were obtained by altering the duration of the exposure at the fixed distance. Prior to use, the UV lamps were allowed to stabilize by turning them on at least $15 \mathrm{~min}$. Minimally processed 'Red Oak Leaf' lettuces were then placed between the radiation lamps over a tray $(106.7 \mathrm{~cm}$ long and $55.88 \mathrm{~cm}$ wide) for the UV-C treatments. The tray consisted in a polystyrene net $(0.02 \mathrm{~mm}$ filament size and $1.5 \mathrm{~cm}$ spacing, DeerBlock Protective Mesh, Easy Gardener, Inc., Waco, Texas, USA) that minimized blockage of the UV-C radiation in a wooden frame. At 18 different places on both sides of the tray, light intensity measurements were taken to determine UV-C intensities without any blockage of the light from the net. The UV-C radiation doses selected for these experiments were: 1.18, 2.37 and $7.11 \mathrm{~kJ} \mathrm{~m}^{-2}$ on each side of the produce. Non-radiated minimally processed 'Red Oak Leaf' lettuce was considered as the control. Radiation of the product was carried out in the fresh-cut preparation room at $10{ }^{\circ} \mathrm{C}$ to avoid a temperature increase between the two banks of lamps during the treatment.

After radiation, fresh-cut 'Red Oak Leaf' lettuce $(100 \mathrm{~g}$ each) were packaged and sealed in $19 \times 25.5 \mathrm{~cm}$ bags of polypropylene (PP) film (Package Concept Corporation, Salinas, California, USA) with an oxygen transmission rate (OTR) of $3100 \mathrm{ml} \mathrm{m}^{-2} \mathrm{day}^{-1} \mathrm{~atm}^{-1}$ (data provided by the film company) and stored at $5^{\circ} \mathrm{C}$ for 10 days.

\subsubsection{Gas composition}

Package atmospheres were monitored throughout the shelf-life. A 20-ml gas sample of headspace was removed 
from designated bags with a sterile airtight syringe and injected onto a $\mathrm{CO}_{2}$ and $\mathrm{O}_{2}$ gas analyzer $(\mathrm{CO} 99673$, Oxygen Sensor and CO95969, Carbon Dioxide Sensor P-61B, AMETEK, Pittsburgh, Pennsylvania 15238, USA).

\subsubsection{Microbial quality}

The microbial counts of the minimally processed 'Red Oak Leaf' lettuce were obtained with standard enumeration techniques (Allende et al., 2004). The following culture media and conditions were used to enumerate the microbial growth: nutrient agar (Difco Lab, Sparks, Maryland, USA) incubated at $30^{\circ} \mathrm{C}$ for $24-48 \mathrm{~h}$ in air for aerobic bacteria and in modified atmospheres $(5 \mathrm{kPa}$ $\mathrm{O}_{2}$ and $20 \mathrm{kPa} \mathrm{CO}_{2}$ ) for facultative aerobic bacteria; PDA with the addition of chloramphenicol $\left(100 \mu \mathrm{g} \mathrm{ml}^{-1}\right)$ (Difco Lab, Sparks, Maryland, USA) incubated at $30^{\circ} \mathrm{C}$ for $48 \mathrm{~h}$ for yeast and fungi; Lactobacilli MRS broth (Difco Lab, Sparks, Maryland, USA) with addition of Bacto ${ }^{\text {TM }}$ agar $\left(10 \mathrm{~g} \mathrm{~L}^{-1}\right)$ (Difco Lab, Sparks, Maryland, USA), incubated at $30^{\circ} \mathrm{C}$ for $72 \mathrm{~h}$ under modified atmosphere $(20 \mathrm{kPa} \mathrm{CO}$ and $5 \mathrm{kPa}$ $\mathrm{O}_{2}$ ) for lactic acid bacteria; McConkey agar (Difco Lab, Sparks, Maryland, USA) incubated at $37^{\circ} \mathrm{C}$ for $24 \mathrm{~h}$ for enteric bacteria. $\mathrm{A} \mathrm{CO}_{2}$ water-jacketed incubator with automatic gas atmosphere composition control (Model 3110, Forma Scientific, Marjetta, Ohio, USA) was used for creating the modified atmosphere. A colony counter (Protos 50,000, Synoptics, Cambridge, UK) was used for enumeration of colonies. Samples for analyses were taken on days 0 (production day), 3, 4, 5, 6, 7, 8, and 10 .

\subsubsection{Sugar and organic acid contents}

A total of $2 \mathrm{~g}$ of lettuce tissue were homogenized with a Polytron homogenizer (Brinkmann Instruments, Westbury, New York, USA), in imidazole buffer (20 mM, pH 7.0). The extracts were centrifuged and the supernatants were dried in vacuo in derivatizing vials following a modified procedure for the derivatization of sugars of Li and Schuhmann (1980). A known amount of $\beta$-phenyl-D-glucopyranoside was included in all samples as an internal standard. A total of $1 \mathrm{ml}$ Trisil reagent (Pierce, Rockford, Illinoios, USA) was mixed vigorously with each sample and then heated at $75^{\circ} \mathrm{C}$ for $30 \mathrm{~min}$. After silylation, $1 \mu \mathrm{l}$ of each derivatized sample was injected into a Hewlett Packard 5890 gas chromatograph (Hewlett Packard, Palo Alto, California, USA) equipped with a flame ionization detector and a 25-m cross-linked methyl silicon gum capillary column (0.2-mm ID, $0.33-\mu \mathrm{m}$ film thickness). Temperatures were as follows: injector $250^{\circ} \mathrm{C}$, detector $275^{\circ} \mathrm{C}$ and column $100-250^{\circ} \mathrm{C}$ programmed at $10^{\circ} \mathrm{C} \mathrm{min}^{-1}$ with 0 min initial and 23 min final times. Organic acids were analysed after extraction with imidazole buffer and purification with a Baker-10 solid phase extraction system. Supernatants from the extract were passed through quaternary amine columns, which were previously conditioned with hexane and methanol. The samples were then eluted from the columns with $0.1 \mathrm{~N}$ $\mathrm{HCl}$. The elutes were concentrated to dryness in vacuo in derivatized vials. Procedures of derivatization and chromatography for organic acids were the same as those for sugars except that column temperature was programmed for $180-250{ }^{\circ} \mathrm{C}$ at $10^{\circ} \mathrm{C} \mathrm{min}^{-1}$ with $3 \mathrm{~min}$ initial and $12 \mathrm{~min}$ final times. The sugars and organic acids were quantified by comparison with a derivatized standard.

\subsubsection{Sensory quality}

The overall visual quality (OVQ) was assessed by three members of an expert sensory panel who rated the product according to an acceptance scale $(1=$ extremely poor, not acceptable; $5=$ lower limit of sales appeal, slightly to moderately objectionable defects; $9=$ excellent, essentially free from defects) to determine the end of the shelf-life of the product (Allende et al., 2002). The product was evaluated after $0,3,4,5,6,7,8$, and 10 days of storage at $5{ }^{\circ} \mathrm{C}$ under conventional passive MAP.

\subsubsection{Experimental design and statistical analysis}

The UV-C radiation of minimally processed ' $R$ ed Oak Leaf' lettuce was conducted in duplicate. Firstly, a preliminary experiment was carried out at two different storage temperatures $\left(5\right.$ and $\left.10{ }^{\circ} \mathrm{C}\right)$, four different UV-C radiation doses $\left(1.18,2.38,7.11\right.$ and $\left.11.8 \mathrm{~kJ} \mathrm{~m}^{-2}\right)$ and a shelf-life of 7 days. Once the selection of the UV-C radiation doses and the storage temperature was done, the main experiment was conducted by applying three radiation doses $\left(1.18,2.38\right.$ and $\left.7.11 \mathrm{~kJ} \mathrm{~m}^{-2}\right)$ and the product was stored at $5{ }^{\circ} \mathrm{C}$ for up to 10 days under passive MAP. A total of 600 bags were prepared for microbial and shelf-life analysis for both experiments. Experimental units were bags and there were three replications per treatment per evaluation period. Results of gas composition and microbial counts are given as the mean and $95 \%$ confidence interval. Statistical analysis of the sensory data was carried out using SAS (Version 8.2, SAS Institute Inc., Cary, North Carolina, USA). Significant differences among treatments were determined using the general linear model (GLM). The preliminary and the main experiment yielded very similar trends.

\section{Results and discussion}

\subsection{Effect of UV-C radiation on the growth of vegetable- associated bacteria}

UV-C resistance differed among the strains. All but four strains were inhibited for growth following a 
$30 \mathrm{~J} \mathrm{~m}^{-2}$ radiation dose. E. carotovora, L. carnosum, $S$. typhimurium, and $Y$. aldovae could grow on plates treated with $55 \mathrm{~J} \mathrm{~m}^{-2}$; however, their growth was inhibited by a UV-C treatment of $85 \mathrm{~J} \mathrm{~m}^{-2}$. Therefore, low radiation UV-C treatments can effectively inhibit the growth of vegetable-associated bacteria isolated from minimally processed vegetables.

\subsection{Effect of $U V$-C radiation on the microbiology, chemical composition and sensory quality of minimally processed 'Red Oak Leaf' lettuce}

\subsubsection{Gas composition}

The $\mathrm{O}_{2}$ and $\mathrm{CO}_{2}$ concentrations within the bags of minimally processed 'Red Oak Leaf' lettuce stored under passive MAP changed throughout the product's shelf-life and was affected by the different treatments (Fig. 2). A faster depletion of $\mathrm{O}_{2}$ and a more rapid increase of $\mathrm{CO}_{2}$ occurred within packages of UV-C treated product relative to the control. Additionally, gas composition varied with the radiation dose. Higher UV-C radiation doses lead to higher $\mathrm{CO}_{2}$ and lower $\mathrm{O}_{2}$ concentrations. As previously reported, UV-C radiation causes respiratory stress in fresh-cut 'Red Oak Leaf' lettuce and increases its respiration rate (Allende and Artes, 2003b). Other reports indicate that non-ionizing UV-C radiation activates several biological processes in higher plants, including the stimulation of respiratory activity (El-Ghaouth and Wilson, 1995; Haram, 1980). Additionally, Maharaj et al. (1999) found that increases in $\mathrm{CO}_{2}$ production in fresh tomato after UV-C radiation were proportional to the applied dose. Erkan et al. (2001) reported that the respiration rates of squash slices were higher in radiated tissue than those of non-radiated controls, and the increase in the respiration rate correlated with the increase in UV-C intensity. However, Vicente et al. (2005) found that UV-C treated peppers displayed a lower respiration rate than untreated control fruit.

A final gas composition of approximately $3-5 \mathrm{kPa} \mathrm{O}_{2}$ and $3-10 \mathrm{kPa} \quad \mathrm{CO}_{2}$ is recommended for fresh-cut produce (Jacxsens et al., 2001). In this study, the final $\mathrm{CO}_{2}$ concentrations were 2.89 and $6.67 \mathrm{kPa}$ for untreated and product treated with the highest UV-C dose. Additionally, the $\mathrm{O}_{2}$ concentrations were $2.18 \mathrm{kPa}$ for product treated with $7.11 \mathrm{~kJ} \mathrm{~m}^{-2}$ and $13.13 \mathrm{kPa}$ for untreated control. Intermediate values were obtained for product radiated with 1.18 and $2.37 \mathrm{~kJ} \mathrm{~m}^{-2}$. As shown in Fig. 2, equilibrium atmospheres were obtained after 6 days and they were within the optimal recommended range in most of the cases. Therefore, the selected $3100 \mathrm{ml} \mathrm{m}^{-2} \mathrm{day}^{-1} \mathrm{~atm}^{-1}$ OTR film was suitable to store UV-C treated minimally processed 'Red Oak Leaf' lettuce.

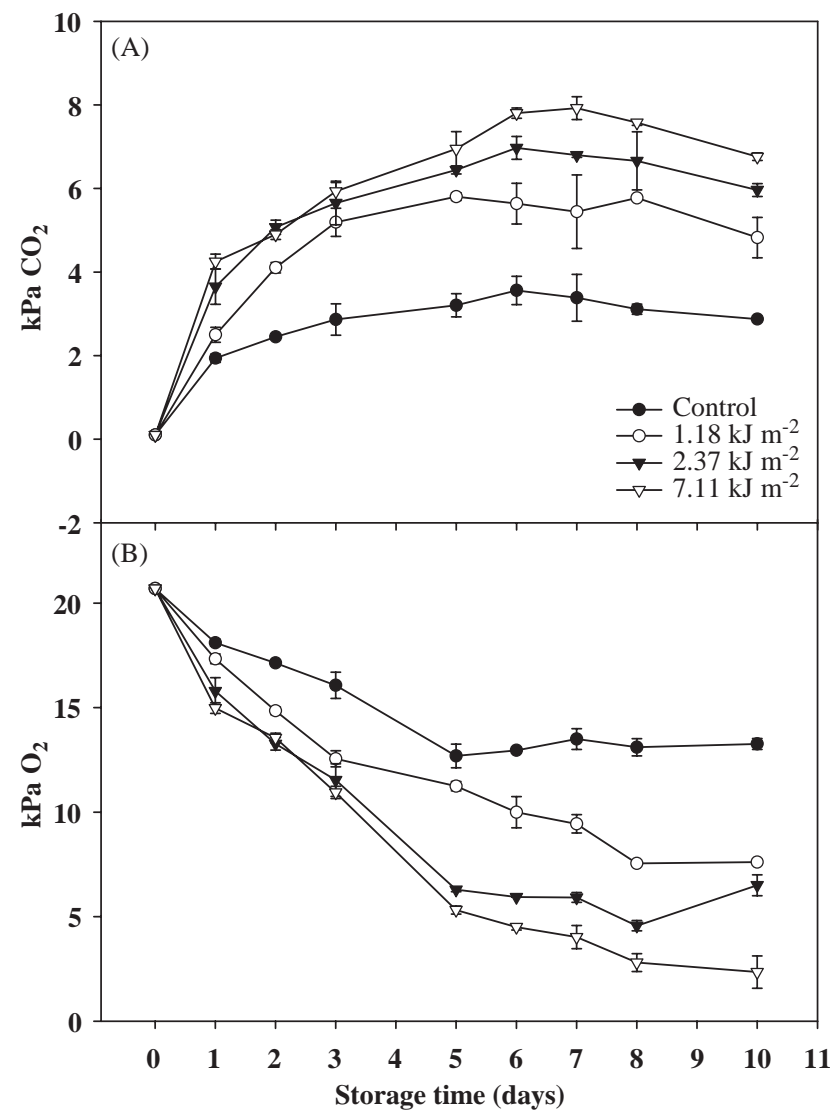

Fig. 2. (A) $\mathrm{CO}_{2}$ and (B) $\mathrm{O}_{2}$ concentrations of non-treated and radiated minimally processed 'Red Oak Leaf' lettuce stored under passive modified atmosphere at $5{ }^{\circ} \mathrm{C}$ for up to 10 days. Bars represent $95 \%$ confidence interval.

\subsubsection{Microbial counts}

The microflora of minimally processed 'Red Oak Leaf' lettuce increased during storage and the microbial counts were within the expected range for fresh-cut vegetable products as described by Nguyen-the and Carlin (1994). Although there were different growth behaviors among bacterial groups, they all responded similarly towards UV-C radiation treatment. UV-C radiation was effective in reducing growth of most of the tested micro-organisms. It was observed that growth of total aerobic and facultative aerobic mesophilic bacteria was lower in radiated samples than in untreated control (Figs. 3A and B). Maximum growth reductions were observed between 2 and 6 days of storage for the higher radiation doses $\left(2.37\right.$ and $\left.7.11 \mathrm{~kJ} \mathrm{~m}^{-2}\right)$. Allende and Artes $(2003 \mathrm{a}, \mathrm{b})$ found similar results when minimally processed 'Lollo Rosso' and 'Red Oak Leaf' lettuces were treated with $0.4,0.81,2.44,4.07$, and $8.14 \mathrm{~kJ} \mathrm{~m}^{-2}$ on only one side of the tissue. Erkan et al. (2001) found that the mesophilic bacterial populations of squash slices were higher in non-radiated controls than in those treated with 0.493 or $9.80 \mathrm{~kJ} \mathrm{~m}^{-2} \mathrm{UV}-\mathrm{C}$ radiation. Therefore, UV-C radiation prolonged shelflife of fresh-cut lettuce based on total microbial counts. 


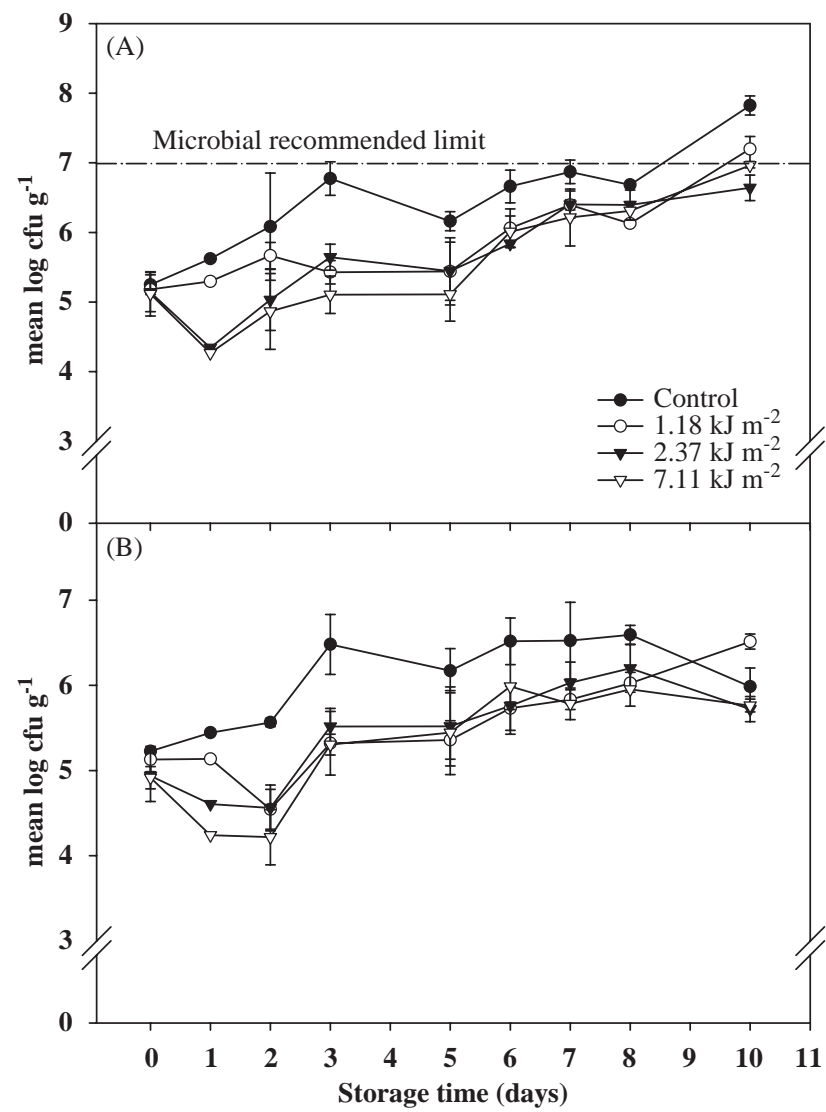

Fig. 3. (A) Total aerobic bacterial growth $\left(\log _{10} \mathrm{cfug}^{-1}\right)$ and (B) facultative aerobic bacteria growth on minimally processed 'Red Oak Leaf' lettuce stored under passive MAP at $5{ }^{\circ} \mathrm{C}$ for up to 10 days. Bars indicate a $95 \%$ confidence interval. The straight line in $\mathrm{A}$ indicates the microbial limit of the Spanish legislation (Boletín Oficial del Estado (BOE), 2001) for total aerobic growth, $7 \log _{10} \mathrm{cfu} \mathrm{g}^{-1}$.

Actually, in compliance with the recommended microbial limit of total plate counts for ready-to-eat vegetables established by the Spanish legislation (Boletín Oficial del Estado (BOE), 2001) $\left(7 \log \mathrm{cfu} \mathrm{g}^{-1}\right)$ or proposed by CNERNA-CNRS (1996) (7.5 $\operatorname{log~cfu~g}^{-1}$ ), the untreated control had a shelf-life that was at least two days shorter than UV-C treated lettuce.

UV-C radiation was effective in reducing lactic acid bacteria when the higher doses $\left(2.37\right.$ and $\left.7.11 \mathrm{~kJ} \mathrm{~m}^{-2}\right)$ were applied (Fig. 4). A difference of about $1 \log$ unit was observed between the untreated control and the radiated product and between 1.18 and $7.11 \mathrm{~kJ} \mathrm{~m}^{-2}$ radiation doses. Similar results were found when the growth of enteric bacteria was evaluated. All the tested UV-C radiation doses were effective in reducing enteric growth after 2 days of storage (Fig. 5). However, no significant difference was observed among the treatments.

Yeast growth was also affected by the radiation treatments. A significant difference was found between the control and radiated samples on all evaluated days except for days 3 and 10 (Fig. 6). No significant

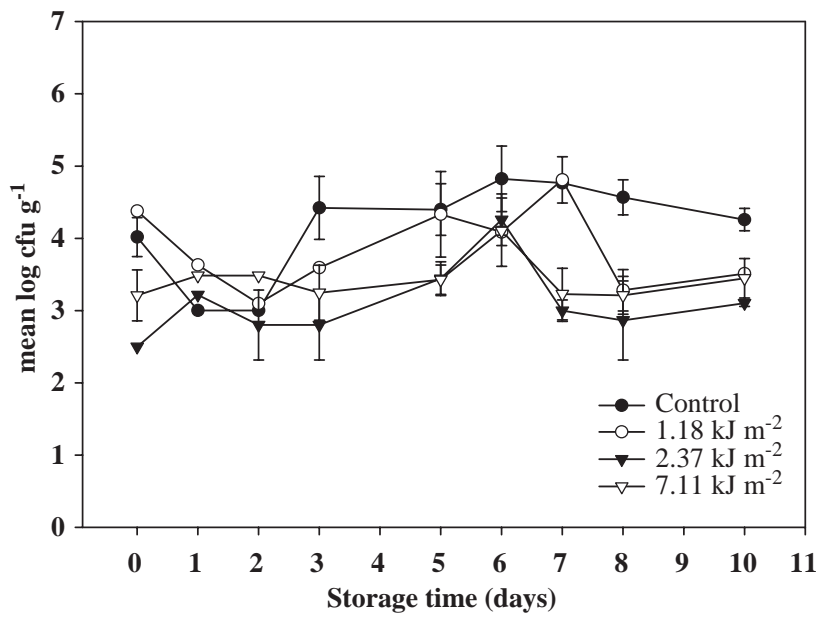

Fig. 4. Lactic acid bacterial growth $\left(\log _{10} \mathrm{cfu} \mathrm{g}^{-1}\right)$ of minimally processed 'Red Oak Leaf' lettuce stored under passive MAP at $5{ }^{\circ} \mathrm{C}$ up to 10 days. Bars indicate a $95 \%$ confidence interval.

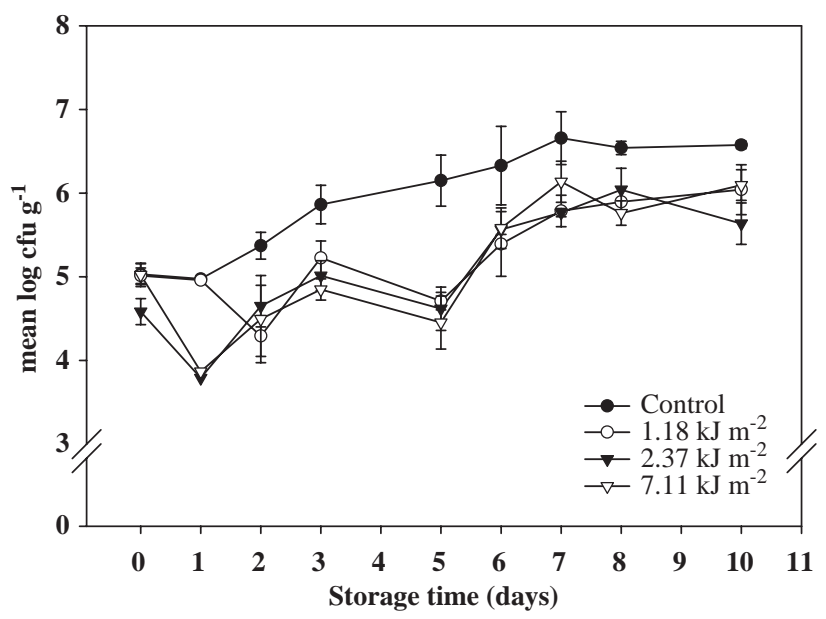

Fig. 5. Enteric bacterial growth $\left(\log _{10} \mathrm{cfu} \mathrm{g}^{-1}\right)$ of minimally processed 'Red Oak Leaf' lettuce stored under passive MAP at $5{ }^{\circ} \mathrm{C}$ up to 10 days. Bars indicate a $95 \%$ confidence interval.

differences between the control and the radiated samples were found at the end of the storage period (day 10) when yeast growth reached a maximum. Due to the influence on sensorial quality of the product, yeast counts often are the limiting micro-organisms for most of the MAP fresh processed vegetables. The recommended limit for yeast and molds is $5 \log \mathrm{cfu} \mathrm{g}^{-1}$ to guarantee the sensory quality (Debevere, 1996). Taking this limit into account, the shelf-life of the product was 1 day longer when $1.18 \mathrm{~kJ} \mathrm{~m}^{-2}$ was applied and 3 days longer when the highest UV-C dose was applied. It was reported that yeast growth in squash slices decreased at least 2 or $3 \log$ units when treated with 4.9 and $9.86 \mathrm{~kJ} \mathrm{~m}^{-2}$ UV-C doses (Erkan et al., 2001).

Ultraviolet radiation causes crosslinks of aromatic amino acids at their carbon-carbon double bonds which 


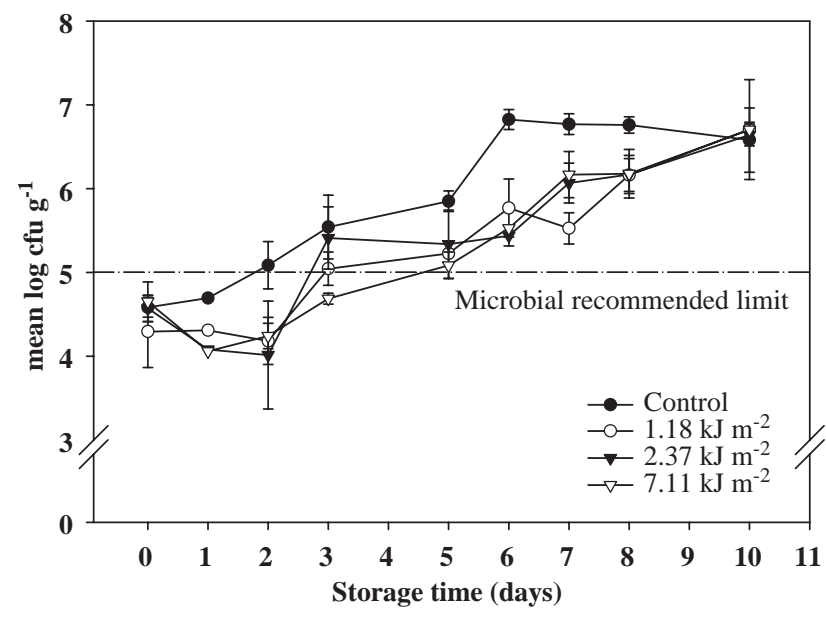

Fig. 6. Yeast growth $\left(\log _{10} \mathrm{cfu}^{-1}\right)$ of minimally processed 'Red Oak Leaf' lettuce stored under passive MAP at $5{ }^{\circ} \mathrm{C}$ up to 10 days. Bars indicate a $95 \%$ confidence interval. The straight line indicates the microbial limit for yeast growth $\left(10^{5} \mathrm{cfu} \mathrm{g}^{-1}\right)$ proposed by Debevere (1996).

lead to membrane depolarization and abnormal ionic flow (Moseley, 1990), photochemical oxidation (Braun and Oliveros, 1997) and pyrimidine dimer formation in DNA strands (Miller et al., 1999). All these factors contribute to its germicidal action. For example, the DNA mutations block the transcription and replication of the cell, compromising cellular functions and often times leads to cell death. It is known that the amount of this DNA cross-linking is proportional to the UV-C exposure. Sommer et al. (1996) reported that the effect of UV radiation on the inactivation of micro-organisms depends on the dose, which is defined as intensity multiplied by the exposure time. It was observed that more than $90 \%$ of the microbial load was affected by the UV-C treatments, since at least $1 \log$ unit reduction was observed after the treatments. However, UV-C radiation is mainly a surface treatment (Jagger, 1965). Therefore, the physical location of the micro-organisms in the product and the different composition of the product may play an important role in the efficiency of the UV-C radiation in reducing microbial loads. Yaun et al. (2004) found that UV-C was more effective at reducing bacterial populations on the surface of apples than on tomatoes and lettuce. It should also be noted that most, if not all, wild-type microbes have a DNA repair system that can excise pyrimidine dimers. This repair process, however, often introduces its own set of mutations in the target DNA that may affect viability and/or growth rate of microbial cells.

\subsubsection{Sugars and organic acids composition}

UV-C treatments used in this experiment have little or no effects on sugar or organic acid content in lettuce (data not shown). Fructose and glucose were the major sugars in the lettuce with sucrose in lesser amounts.
Citric and malic acids were the predominant organic acids. Total sugars and organic acids decreased with time during storage in all treatments. However, no significant differences were found among various treatments $\left(1.18-7.11 \mathrm{~kJ} \mathrm{~m}^{-2}\right)$ in this study. Similar findings were reported from Erkan et al. (2001) on zucchini squash tissue. In fruit that involve the ripening process (e.g. mangoes), UV-C radiation was found to increase sugar levels and decrease organic acid levels probably as a result of enhancing the ripening process (GonzalezAguilar et al., 2001).

\subsubsection{Sensory quality}

The OVQ of the product was evaluated to determine the limit of acceptability from the consumer point of view. In the present study, no significant difference was observed among treatments except for the highest UV-C treatment. A dose of $7.11 \mathrm{UV}-\mathrm{C} \mathrm{kJ} \mathrm{m}{ }^{-2}$ induced tissue softening and increased browning after 7 days of storage at $5{ }^{\circ} \mathrm{C}$. Ben-Yehoshua et al. (1992) observed an abiotic stress produced by UV illumination beyond a certain threshold dose, which exerted visible damage to the peel of citrus fruits. Additionally, a dose of $24.4 \times 10^{3} \mathrm{~J} \mathrm{~m}^{-2}$ was found to provoke ripening and caused abnormal browning, manifested as sun-scalding of the tomato fruit's surface (Maharaj et al., 1999). The softening of lettuce subjected to the highest UV-C radiation could be related to the production of free radicals as a result of increase in senescence (Leshem et al., 1986) and its effect on the cell wall. The softening of tissues during ripening results in part from progressive changes in cell wall composition as well as cell wall separation (Maharaj et al., 1999). Cell wall separation is brought about by the solubilization of the pectin-rich lamella (Brady, 1987).

The end of the shelf-life for 'Red Oak Leaf' lettuce in other UV-C treatments was established to be 8 days of storage at $5{ }^{\circ} \mathrm{C}$ according to the limit of acceptability. Several studies showed the beneficial effect of UV-C radiation retarding decay as well as in delaying senescence in different fruit and vegetables (Erkan et al., 2001; Liu et al., 1993; Maharaj et al., 1999; Mercier et al., 2001; Stevens et al., 1998; Wilson et al., 1997). Allende and Artes (2003a,b) found no significant difference between untreated and radiated fresh-cut lettuce with a maximum radiation dose of $8.14 \mathrm{~kJ} \mathrm{~m}^{-2}$. More recently, Vicente et al. (2005) have found that UV$\mathrm{C}$ treatments reduced decay in peppers $\mathrm{cv}$. Zafiro with low radiation doses.

\section{Conclusions}

In this study, UV-C radiation was applied to both sides of the product at the same time simulating a continuous production chain. The obtained results confirm previous findings about the effectiveness of 
microbial reductions in fresh cut lettuce by using short exposure times and low radiation doses. All the analysed microbial groups were reduced by UV-C radiation throughout most of the sampling period. Additionally, the sugars and organic acids of the lettuces were not significantly affected by UV-C radiation. The OVQ of the product was not significantly affected except when the highest UV-C radiation dose $\left(7.11 \mathrm{~kJ} \mathrm{~m}^{-2}\right)$ was used. A UV-C dose of $2.37 \mathrm{~kJ} \mathrm{~m}^{-2}$ was effective in reducing microbial growth without affecting the overall quality of minimally processed 'Red Oak Leaf' lettuce. Therefore, it was concluded that UV-C radiation applied at proper doses and to both sides of the product could reduce microbial growth and extend shelf-life without adversely affecting quality of 'Red Oak Leaf' lettuce.

\section{Acknowledgement}

I would like to thank Irving Newman for constructing the UV radiation device.

\section{References}

Abshire, R.L., Dunton, H., 1981. Resistance of selected strains of Pseudomonas aeruginosa to low-intensity ultraviolet radiation. Appl. Environ. Microbiol. 41, 1419-1423.

Allende, A., Artes, F., 2003a. UV-C radiation as a novel technique for keeping quality of fresh processed 'Lollo Rosso' lettuce. Food Res. Int. 36, 739-746.

Allende, A., Artes, F., 2003b. Combined ultraviolet-C and modified atmosphere packaging treatments for reducing microbial growth of fresh processed lettuce. Lebensm. Wiss. Technol. 36, 779-786.

Allende, A., Jacxsens, L., Devlieghere, F., Debevere, J., Artes, F., 2002. Effect of super atmospheric oxygen packaging on sensorial quality, spoilage, and Listeria monocytogenes and Aeromonas caviae growth in fresh processed mixed salads. J. Food Prot. 65, 1565-1573.

Allende, A., Luo, Y., McEvoy, J.L., Artes, F., Wang, C.Y., 2004. Microbial and quality changes in minimally processed baby spinach leaves stored under super atmospheric oxygen and modified atmosphere conditions. Postharvest Biol. Technol. 33, 51-59.

Ben-Yehoshua, S., Rodov, V., Kim, J.J., Carmeli, S., 1992. Preformed and induced antifungal materials of citrus fruits in relation to the enhancement of decay resistance by heat and ultraviolet treatments. J. Agric. Food Chem. 40, 1217-1221.

Bintsis, T., Litopoulou-Tzanetaki, E., Robinson, R.K., 2000. Existing and potential applications of ultraviolet light in the food industry-a critical review. J. Sci. Food Agric. 80, 637-645.

Boletín Oficial del Estado (BOE), 2001. Normas de higiene para la elaboración, distribución y comercio de comidas preparadas, Madrid, Spain, Real Decreto 3484/2000, pp. 1435-1441.

Brady, C.J., 1987. Fruit ripening. Ann. Rev. Plant Physiol. 38, $155-178$.

Braun, A.M., Oliveros, E., 1997. How to evaluate photochemical methods for water treatment. Water Sci. Technol. 35, 17-23.

Brecht, J.K., Chau, K.V., Fonseca, S.C., Oliveira, F.A.R., Silvae, F.M., Nunes, M.C.N., Bender, R.J., 2003. Maintaining optimal atmosphere conditions for fruits and vegetables throughout the postharvest handling chain. Postharvest Biol. Technol. 27, 87-101.
CNERNA-CNRS, 1996. Produits de la IVe gamme. In: Jouve, J. (Ed.), La qualité microbiologique des aliments (maîtrise et critères), second ed. Polytechnica, Paris, France, pp. 73-98.

Debevere, J., 1996. Criteria en praktische methoden voor de bepaling van de houdbaarheidsdatum in de etikettering. In: Etikettering, houdbaarheid en bewaring (voedingsmiddelen en recht 2). Die Keure, Brugge, Belgium, pp. 37-64.

El-Ghaouth, A., Wilson, C.L., 1995. Biologically based technologies for the control of postharvest diseases. Postharvest News Inform. 6, 5-11.

Erkan, M., Wang, C.Y., Krizek, D.T., 2001. UV-C radiation reduces microbial populations and deterioration in Cucurbita pepo fruit tissue. Environ. Exp. Bot. 45, 1-9.

Francis, G.A., Thomas, C., O'Beirne, D., 1999. The microbiological safety of minimally processed vegetables. Int. J. Food Sci. Technol. $34,1-22$.

Gardner, D.W., Shama, G., 2000. Modeling UV-induced inactivation of microorganisms on surfaces. J. Food Prot. 63, $63-70$.

Gonzalez-Aguilar, G.A., Wang, C.Y., Buta, J.G., Krizek, D.T., 2001. Use of UV-C radiation to prevent decay and maintain postharvest quality of ripe 'Tommy Atkins' mangoes. J. Food Sci. Technol. 36, $767-773$.

Haram, W., 1980. Biological effects of ultraviolet radiation. In: Haram, W. (Ed.), Biological Effects of Ultraviolet Radiation. Cambridge University Press, Cambridge, UK.

Jacxsens, L., Devlieghere, F., Van der Steen, C., Debevere, J., 2001. Effect of high oxygen modified atmosphere packaging on packaging on microbial growth and sensorial qualities of fresh-cut produce. Int. J. Food Microbiol. 71, 197-210.

Jagger, J., 1965. Photoprotection from far ultraviolet effects in cells. In: Duchesne, J. (Ed.), Advances in Chemical Physics, vol. VII. The Structure and Properties of Biomolecules in Biological Systems. Interscience, New York, pp. 548-601.

Leshem, Y.Y., Halevy, A.H., Frenkel, C. (Eds.), 1986. Free Radicals and Senescence. Elsevier, New York, pp. 100-166.

Li, B.W., Schuhmann, P.J., 1980. Gas-liquid chromatographic analysis of sugars in ready-to-eat breakfast cereals. J. Food Sci. 45, 138-141.

Liu, J., Stevens, C., Khan, V.A., Lu, J.Y., Wilson, C.L., Adeyeye, O., Kabwe, M.K., Pusey, P.L., Chalutz, E., Sultana, T., Droby, S., 1993. Application of ultraviolet-C light on storage rots and ripening of tomatoes. J. Food Prot. 56, 868-872.

Maharaj, R., Arul, J., Nadeau, P., 1999. Effect of photochemical treatment in the preservation of fresh tomato (Lycopersicon esculentum cv. Capello) by delaying senescence. Postharvest Biol. Technol. 15, 13-23.

Marquenie, D., Michiels, C.W., Van Impe, J.F., Schrevens, E., Nicolaï, B.N., 2003. Pulsed white light in combination with UV$\mathrm{C}$ and heat to reduce storage rot of strawberry. Postharvest Biol. Technol. 28, 455-461.

Mercier, J., Baka, M., Reddy, B., Corcuff, R., Arul, J., 2001. Shortwave ultraviolet radiation for control of decay caused by Botrytis cinerea in bell pepper: induced resistance and germicidal effects. J. Am. Soc. Hortic. Sci. 126, 128-133.

Miller, R., Jeffrey, W., Mitchell, D., Elasri, M., 1999. Bacterial responses to ultraviolet light. Am. Soc. Microbiol. 65, 535-541.

Moseley, B.E.B., 1990. In: Johnston, D.E., Stevenson, M.H. (Eds.), Food irradiation and the chemist. Royal Society of Chemistry, Bristol, pp. 97-108.

Nguyen-the, C., Carlin, F., 1994. The microbiology of minimally processed fresh fruits and vegetables. CRC Crit. Rev. Food Sci. Nutr. 34, 371-401.

Rhim, J.W., Gennadios, A., Fu, D., Weller, C.L., Hanna, M.A., 1999. Properties of ultraviolet irradiated protein films. Lebensm. Wiss. Technol. 32, 129-133. 
Saltveit, M.E., 2003. Is it possible to find an optimal controlled atmosphere? Postharvest Biol. Technol. 27, 3-13.

Schoenen, D., Kolch, A., 1992. Photoreactivation of E. coli depending on light intensity after UV irradiation. ZBL Hyg. Umweltmed. 192, $565-570$.

Soliva-Fortuny, S.C., Martín-Belloso, O., 2003. New advances in extending the shelf life of fresh-cut fruits: a review. Trends Food Sci. Technol. 14, 341-353.

Sommer, R., Haider, T., Cabaj, A., Heidenreich, E., Kundi, M., 1996. Increased inactivation of Saccharomyces cerevisiae by protraction of UV radiation. Appl. Environ. Microbiol. 62, 1977-1983.

Sommer, R., Lhotsky, M., Haider, T., Cabaj, A., 2000. UV inactivation, liquid-holding recovery, and photoreactivation of $E$. coli $\mathrm{O} 157$ and other pathogenic E. coli strains in water. J. Food Prot. 63, 1015-1020.

Stevens, C., Khan, V.A., Lu, J.Y., Wilson, C.L., Pusey, P.L., Kabwe, M.K., Igwegbe, E.C.K., Chalutz, E., Droby, S., 1998. The germicidal and hormetic effects of UV-C light on reducing brown rot disease and yeast microflora of peaches. Crop Prot. 17, 75-84.
Sumner, S.S., Wallner-Pendleton, E.A., Froning, G.W., Stetson, L.E., 1995. Inhibition of Salmonella typhimurium on agar medium and poultry skin by ultraviolet energy. J. Food Prot. 59, 319-321.

Vicente, A.R., Pineda, C., Lemoine, L., Civello, P.M., Martinez, G.A., Chaves, A.R., 2005. UV-C treatments reduce decay, retain quality and alleviate chilling injury in pepper. Postharvest Biol. Technol. $35,69-78$.

Wilson, C.L., El Ghaouth, A., Upchurch, B., Stevens, C., Khan, V., Droby, S., Chalutz, E., 1997. Using an on-line UV-C apparatus to treat harvested fruit for controlling postharvest decay. Technol. Prod. Rep. 7, 278-282.

Wong, E., Linton, R.H., Gerrard, D.E., 1998. Reduction of E. coli and Salmonella senftenberg on pork sink and pork muscle using ultraviolet light. Food Microbiol. 15, 415-423.

Yaun, B.R., Summer, S.S., Eifert, J.D., Marcy, J.E., 2004. Inhibition of pathogens on fresh produce by ultraviolet energy. Int. J. Food Microb. 90, 1-8.

Yousef, A.E., Marth, E.H., 1988. Inactivation of Listeria monocytogenes by ultraviolet energy. J. Food Sci. 53, 571-573. 